\title{
The Construction of Training System of Professional Talents of Financial Management on Mode of School-enterprise Cooperation
}

\author{
Weiliu Yang \\ Department of Economics and Management \\ Zaozhuang University \\ Zaozhuang, China \\ yangweiliu@163.com
}

\author{
Chuanzhou Zhang \\ Department of Economics and Management \\ Zaozhuang University \\ Zaozhuang, China \\ zhangcz1968@sina.com
}

\begin{abstract}
In recent years, China's government has been promoting enterprises to participate in the construction of curriculum reform of colleges and universities. Enterprises and universities set up bases for training or employment jointly. This can not only promote the combination of theory and practice of college students, but also improve the students' employment rate. In addition, it allows enterprises find talents which suitable for enterprise's development and progress, and it is helpful for the students to adapt to the requirements of the enterprise and the work position. Therefore, school-enterprise cooperation has become an important breakthrough in the transformation of application oriented undergraduate university. In the mode of school-enterprise cooperation, the construction of major and talent cultivation system is very important. This paper aims to analyze the construction of training system of professional talents of financial management on mode of school-enterprise cooperation.
\end{abstract}

Keywords-financial management; training system; schoolenterprise cooperation; talent cultivation system

\section{INTRODUCTION}

In the notice issued by the Ministry of Education, the Key Points of Work for the Ministry of Education in 2017 points out that deepen the reform of personnel training mode, issued and implemented the national standards for the quality of undergraduate training, implemented the demonstration projects of school-enterprise cooperation deeply. Schoolenterprise cooperation is an important issue in the development of local undergraduate colleges and universities, and the cooperation between schools and enterprises is an important driving force for the development of financial management major. Financial management is a comprehensive subject of economics, management, accounting and other disciplines, its theory is complicated, and it emphasizes the practicality and applicability [1]. In recent years, with the development of economic and social, the general undergraduate colleges and universities transform to the application-oriented colleges, and students major in financial management will be cultivated to applicable talents. Universities and colleges should first clear enterprises' requirements about financial position [2-3]. The cooperation between school and enterprise will be the bridge between universities and social, and it is the real way to achieve the goal of training application-oriented talents. In the trend of school-enterprise cooperation, the improvement of personnel quality has become a competitive way between schools, but the determining factor is the construction of cultivation of talent system. The school-enterprise cooperation is still in the initial stage, the construction of system is not be applied mechanically, but according to the developmental orientation of the school, the specific needs of regional industry and the characteristics of enterprises. By increasing the intensity of school-enterprise cooperation, sharing of resources between schools and enterprises, taking advantages of other enterprises, the quality of financial management talents will be improved greatly.

The major financial management of Zaozhuang University applies and sets up in 2005 and through the evaluation next year and begins recruit students. The major has been six years till now, and there are more than 1,400 graduates. They have been well wanted by social, and they joined in different kinds of industries. This is closely integrated with economic development of Zaozhuang city even Shandong province and social needs of the market.

After more than 10 years of development, the number of financial talents has increased, and the quality of talents has been improved. The personnel training program has been modified many times and reasonable curriculum system has been constructed now. Training bases cover a wide range of areas, and enterprises have carry out in-depth cooperation with school.

In 2015 the Ministry of Education issued Guiding Opinions on Guiding the Transformation of Applied Undergraduate Universities, it pointed out that the mechanism of cooperative education and cooperative governance should be established by schools, the local, industry, enterprises and the community jointly, and make the School-enterprise cooperation in the professional cluster to achieve full coverage. Universities can be with the industry and enterprises to set up educational groups, or with industry enterprises, industrial clusters to build co-management secondary colleges. In 2015,the college of Economic and Management and TEDU Education Group signed contracts to set up the Financial Management (Accounting). From the past two years, the enrollment plan had 
been done well. It shows that the professional makes close contact with current social needs. The college of Economic and Management and TEDU Education Group have developed the personnel training program of Financial Management (Accounting) professional. Due to the lack of experience, the program and the training systems need to be further revised. The subject based on the problem of financial management professional talents training, it aims to explore the construction of training system of professional talents of financial management on mode of school-enterprise cooperation, and deepen teaching reformation, optimize the curriculum system, strengthen the construction of teaching staff, and it guided by the policy "to serve the local characteristics of the development", building teaching practice base actively, strengthening the cooperation between school and enterprise, and improving the quality of personnel training, trying to construct the specialty with high social reputation and serving the local [4].

The system of training was discussed by experts and teachers insides and outside of school and TEDU Education Group. The training plan of 2017 has been revised and completed according to the latest spirit of the document and credit reform. Students major in financial management (Accounting) should learn 4 years and finish 160 credits. The curriculum system of the talent training program is "platform\& module" with 45 credits for general education courses, 36 credits for subject education programs, 46 credits for professional education programs, 10 credits for innovation and entrepreneurship modules, and 23 credits for practical teaching courses. The practice credits account for 31.88 percent of the total credits. It meets the standard of the Guidance of Some Local Colleges and Universities Turn to Application-oriented Schools issued by the Ministry of Education, and it meets the need of transformation of talent training. The specific curriculum structure shows as follows:

\section{PROBLEMS IN FINANCIAL MANAGEMENT TALENTS TRAINING SYSTEM ON MODE OF SCHOOL-ENTERPRISE} COOPERATION

\section{A. Talent training system lacks market orientation, and graduates cannot meet the need of enterprises}

With the development of transformation and cooperation, the reconstruction of personnel training system has become an important subject. In terms of the specialty of financial management, the graduates should become applied talents. Because companies always prefer students have practical skills. While the current training system including many traditional and complex curriculums. Different experts have different opinions on the reconstruction, and different financial positions have different requirements, which bring difficulties to the design of personnel training program. There is no clear division in the training directions, the talents are always "generalist", while businesses are often to employee "professionals". Therefore, in general, the current training system cannot adapt to the requirements of the enterprise due to the lack of market orientation. The training plan formulated most by teachers lacking of practical experiences instead of the practical experts. It is difficult for the teachers to put forward constructive suggestions, so the training plan cannon meet the society's need and graduates cannot adapt to the job.

\section{B. The concept of teachers has not changed, and they cannot be competent for practical teaching}

At present, the financial management professional course teaching is still based on theoretical teaching. Professional teachers are accustomed to professional theory classroom teaching, and they are not willing or cannot carry out experimental teaching. Many universities regard the schoolenterprise cooperative major as ordinary major, and neglect the differences between them. So students from different majors on the same class, and the training plan cannot work well. In addition, under the background of school-enterprise cooperation, some courses are completed by enterprises and schools, and some courses are entirely by experts from the enterprises [5]. Firstly,the number of teaching hours is not enough. Secondly, the courses are often arranged before the graduation, freshman and sophomore have less opportunity to join, while junior and senior put their time on taking a graduate exam or civil service exam. The effect of expert teaching is not good. Thirdly, there is less cooperation between business experts and school teachers, the number and time of professional teachers to participate in the practice of training should be increased.

\section{Case teaching has limited effect on student in comprehensive ability}

In order to improve students' practical ability and adapt themselves to job' requirements, many teachers use case teaching. Curriculum system also includes case teaching. Case teaching is an important way to improve comprehensive ability of students. Many teachers try to combine theory with practice by using case teaching in theoretical teaching. But some cases have been outdated. While teachers don't want pay too much attention on case creation. Students don't know the case's background, so they cannot understand the case well. And case teaching cannot work well. In a way, case teaching plays a minor role in cultivating the ability to think independently and study the question. Some universities have built comprehensive simulation laboratory with less hardware and software because of the lack of fund. So that students have less experimental lessons than theoretical lessons. A lot of graduates have no contact with financial software, so they cannot do job well. With the development of school-enterprise cooperation, companies will invest more in school hardware. The laboratory is building now, and relevant person in charge will pay more attention on the construction of the training plan.

\section{THE STRATEGY OF CONSTRUCTION OF TALENT RAINING} SYSTEM ON THE MODE OF SCHOOL-ENTERPRISE COOPERATION

\section{A. Building a win-win platform for school-enterprise cooperation}

At present, the school-enterprise cooperation has become a new trend, but still in the initial stage. Most of the cooperation focus their attention on provide hardware facilities, practice base and teacher training. There is a long way to the real cooperation. To reach the goal, the school should be precise 
positioning and establishing a mechanism for win-win cooperation and sustainable development. Take improving students' quality as the starting point and make professional and industry together. The leader is responsible for communication while the teacher make less contact with company. The training plan and the mechanism haven't finished. How to establish a sound cooperation mechanism where resource integration and sharing can be achieved, teachers can communicate with experts, students can participate in is an important part of school-enterprise cooperation. Trying to establish the media platform of information sharing, combining recourses online and offline, establish the interactive mechanism of enterprises, schools, teachers and students, defining everyone's rights and obligations in the construction of training system and teaching staff, curriculum and course construction and so on.

\section{B. Establish talent training system jointly}

At present, the establishment of the talent training plan and system is mainly carried out by school. The plan should be completed by the school and enterprise. Industry experts and business professionals should be invited to participate in the program development. The plan should be adjusted according to the social and economic development. The curriculum should be designed to meet the needs of the society. These curriculums such as extracurricular, university students' innovative undertaking, cases of entrepreneurs' qualityextended training should be added to the financial management personnel training program in order to meet the demand for innovation driven development strategy of "Mass innovation and Peoples innovation” at present. Additionally, in order to satisfy the demand for promotion and application of management accounting, the cost accounting and the management accounting should also be added [6]. Personnel training program and curriculum design should be adjusted dynamically. However, the practice training curriculum presents these features that relatively general and no updated, the new knowledge and new technology rarely added, the content is old fashioned. This curriculum has failed to integrate with economy development and applied personnel training. Management accounting can be taught by school-enterprise cooperation, financial statement analysis, accounting cases analysis and accounting management cases analysis such as TEDU Education Group came into the market in the USA. These curriculums are taught by financial experts. In this process, financial expert act as an example to others with new content and actual cases, thus the students can acquire financial knowledge of USA listed company. The content of practice teaching is more actual and forceful, and the teaching efficiency will be higher. Furthermore, adding the course credit and credit hours can satisfy the need of practice teaching in the process of personnel training program. In the case of financial management, the revised scheme of financial management professional personnel adds financial management experimental training course, the credits proportion of practice curriculum increases [7].

\section{Strengthening teaching staff construction, developing teaching staff of the school-enterprise community}

Under the background of undergraduate university transformation, the quality of talents depends largely on the level of teachers. Now, most of teachers in colleges are young, they accept a higher education but lack of business practice background. The number of "double-qualified teachers" is small. So it is necessary for universities to improve teachers' comprehensive qualities from "education \& experience" and construct the teaching staff. Developing teaching staff of the school-enterprise community is the inevitable choice of schoolenterprise cooperation in running schools. Experts from enterprises give few lessons, so that school teachers must carry out theoretical and practical teaching. It is imperative to realize the transitional development of teachers. University should be make plans which organizing teachers to conduct full time practice in company. In addition, teachers should communicate and make contact with company. Changing the needs of enterprises into a research program and establishing research team can not only solve companies' financial problems but also improve teachers' practical ability. Strengthen the communication between school and enterprise, and some teachers should be assigned to train in company and exchange ideas with experts. All these solutions will lay the foundation for school-enterprise cooperation. Teachers are encouraged to take a series of qualification certificates such as CPA, Accountant qualification certificate and Financial Planning. They can obtain the latest theories and policies by taking exams [8]. This action will not only understand the position need but also lay the foundation for construction of "doublequalified teachers” team. For another, schools can engage experts and experienced financial managers as distinguished professor. They can make full use of their business advantage and social function to know about students and expand employment channels for students. This provides a guarantee for the cultivation of applied talents.

\section{Attach equal importance to both theory teaching and practice teaching, exploring practical teaching project management}

The important orientation of school-enterprise cooperation is to strengthen students' practical ability and strive to improve the proportion of practical teaching. It not means theory teaching can be ignored. Transformation of undergraduate colleges and universities is not to vocational colleges. Students' theoretical knowledge acquisition is indispensable. Students should have solid theory to practice. With the development of economy and society, we implemented the strategy of innovation-driven development and Internet plus, new theory, new system and new phenomenon emerging constantly. All of these put forward high requirements for financial managers. Financial managers should have the most advanced theoretical knowledge and comprehensive practice ability. Only in this way can they adapt to the society. Theory teaching contents should be update. Teachers should explore new teaching methods in order to lay foundations for practical teaching.

In addition, to implement project management, control whole processes, standardize each link for the purpose of guaranteeing the quality of practice teaching. Make sure 
students understand the importance of practice courses when they have professional education and practice in company. Encourage students to take part in financial competition and award them. Let student know the importance, aims, contents and testing standard of practice learning and pay more attention to it through SRT project. Teachers should guide students to know the requirement of the position and the way to work when having practice courses, and make sure students accomplish the task well [9]. When the practice training finished, teachers will help students with comprehensive summary. The students are asked to submit summary report, and they will have competition with teams. Then teachers will summarize and make improvement. The implements of project management in the whole process will improve teaching results.

\section{E. Enhancing the course construction, stimulating students' interest in studying course by used many ways}

Traditional practice course system includes case teaching, laboratory training, and external-campus practice. Under the background of school-enterprise cooperation, there are many kinds of teaching methods. Firstly, school can invite company's experts to make special reports about finance. Secondly, teachers should seek horizontal subject actively, and enterprise can provide school for research subjects about management. Then teachers and students can finish this research together. Thirdly, ERP Sand Table Simulation Training is a behavioral process about comprehensive simulation of business management by electronic sand table or manual sand table. Fourthly, encourage students to take part in financial competition. The contest can reflect how good students' comprehensive ability is. Students' ability can be improved though contest every year. Different ways of practice teaching may widen student's field of vision and improve abilities of knowledge application. It can also improve students' ability to solve problems. What's more, it can arouse students' enthusiasm. Virtual simulation educational training system which covered the whole accounting profession should be built. Many universities have built multi-disciplinary comprehensive training simulation laboratory, for example, the VBSE multi-disciplinary comprehensive training platform of accounting college in Heilongjiang Bayi Agricultural University. Students actively participate in this training course, and the efficiency is higher compared with classroom teaching. In addition, the university cooperate with company can develop the financial management teaching software with practical operability and adaptability in the existed laboratory condition [10]. TEDU Education Group has innate advantage of developing computer software, one practical training software fits universities can be developed which comprehensive considers the need of financial position, teachers and students in the later process of cooperation. Practical teaching materials absence relatively and some practical teaching materials should coordinate with relevant practical training software. Therefore, school-enterprise cooperation compile curriculum materials will improve the practical teaching efficiency. The universities should actively conduct curriculum reform closely.

\section{CONCLUSION}

With the steadily improvement of market economy, innovation of science and technology, high-level financial management talents in China still face a serious shortage phenomenon. As an economy-prosperous province, peninsula blue economic zone construction of Shandong Province has become national strategy. The rapid development of economy and the continuing promotion of industries structure in Shandong Province inevitably increase the demand for financial management talents. As a city of resources transformation, Zaozhuang is actively building "Two Highlands”, promoting the economy development and industries structure and expediting new urbanization construction. The demand for financial management talents also will increase. The school-enterprise cooperation for financial management should grasp this chance and improve the quality of training students with the opportunity of Shandong Province's and Zaozhuang's development. Its corner is professional talents training system. Professional talents training system for financial management should be reformed, and a complete financial management training system not only fits the need of economic society but also satisfies the demand for occupation position should be formed.

\section{ACKNOWLEDGMENT}

This research was financial supported by Key Program of Teaching Reformation of Zaozhuang University: The construction of professional financial management talents training system based on School-enterprise cooperation mode.

\section{REFERENCES}

[1] S. Lan, Y.P. Guo, "Preliminary Study of College-enterprise cooperation's driving power source in financial management,” Journal of Yangling vocational \& technical College, vol. 2, pp. 35-39, 2011.

[2] P. Huang, "Research on the training mode of applied talents in financial management,” Journal of Tongling University, vol. 4, pp. 123-126, 2016.

[3] G.J. Lin, “Accounting personnel university-enterprise cooperation training mode,” Journal of Hunan City University(Natural Science), vol. 4, pp. 290-291, 2016.

[4] C.B. Hao, "Deepen the School-enterprise cooperation to improve the quality of applied talent training," Value Engineering, vol. 22, pp.180183, 2016.

[5] P. Huang, "Research on the training mode of applied talents in financial management,” Journal of Tongling University, vol. 4, pp. 123-126, 2016.

[6] G.J. Lin, “Accounting personnel university-enterprise cooperation training mode,” Journal of Hunan City University(Natural Science), vol. 4, pp. 290-291, 2016.

[7] C.B. Hao, "Deepen the School-enterprise cooperation to improve the quality of applied talent training," Value Engineering, vol. 22, pp. 180183, 2016.

[8] S.X. Tan, "Research on the construction of accounting talents training model under the cooperation between colleges and enterprises,” Journal of Harbin Institute of Vocational Technology, vol. 6, pp. 64-66, 2016.

[9] Y. L. Qiu, "Research on the talent cultivation model of "dual system" under the cooperation between colleges and enterprises," Education and Teaching Forum, vol. 35, pp. 243-244, 2016.

[10] M. Song, "Research on the Cultivation of Compound Talents in Universities under the Cooperation of School and Enterprise," China Business \& Trade, vol. 4, pp. 183-184, 2017. 